\title{
Localisation of somatostatin and somatostatin receptors in benign and malignant ovarian tumours
}

\author{
GH Hall*,', LW Turnbull', I Richmond ${ }^{2}$, L Helboe ${ }^{3}$ and SL Atkin ${ }^{4}$ \\ 'Department of Radiology, University of Hull, Centre for Magnetic Resonance Investigations, Hull Royal Infirmary, Anlaby Road, Hull, HU3 2JZ, UK; \\ ${ }^{2}$ Department of Pathology, Hull Royal Infirmany, Anlaby Road, Hull, HU3 2JZ, UK; ${ }^{3}$ Neurobiology, H. Lundbeck A/S, Ottiliavej 7, DK-2500 Valby, \\ Denmark; ${ }^{4}$ Department of Diabetes and Endocrinology, University of Hull, Michael White Diabetes Centre, Hull Royal Infirmary, Anlaby Road, Hull, HU3 \\ 2JZ, UK
}

Somatostatin has been identified as having anti-proliferative, anti-angiogenic and pro-apoptotic actions in many tumour systems, and these effects are mediated through a family of five transmembrane G-protein coupled SRIF receptors. Ovarian cancer is the commonest gynaecological malignancy in the UK and maintenance therapy is urgently required. Native somatostatin expression and its receptors sst, 2,3 and 5 were studied with immunohistochemistry in 63 malignant and 35 benign ovarian tumours of various histological types. Fifty-seven out of 63 (90\%) of malignant and 26/35 (74\%) benign tumours expressed somatostatin. Receptors sst, 1,3 and 5 were expressed variably in epithelial, vascular and stromal compartments for both benign and malignant tumours. Somatostatin was found to correlate significantly with stromal sst, $(P=0.008)$, epithelial sst $_{1}(P<0.00 \mathrm{I})$, stromal sst $2(P=0.019)$, $\operatorname{vascular~sst}_{2}(P=0.026)$, epithelial sst $3(P=0.026)$, stromal sst $5(P=0.013)$ and vascular sst $_{5}(P=0.038)$. Increased expression of native somatostatin correlating with somatostatin receptors in malignant ovarian tumours raises the possibility that either synthetic somatostatin antagonists or receptor agonists may have therapeutic potential.

British Journal of Cancer (2002) 87, 86-90. doi:10.1038/sj.bjc.6600284 www.bjcancer.com

(C) 2002 Cancer Research UK

Keywords: somatostatin; somatostatin receptors; ovarian cancer; immunohistochemistry; angiogenesis

\section{INTRODUCTION}

Ovarian cancer is the commonest of the gynaecological malignancies in the western world with over 5000 new cases per annum in the UK (Office for National Statistics, 1998) and an overall 5-year survival of under $30 \%$. Current therapy relies on debulking surgery with adjuvant chemotherapy, but relapse is common and development of an effective maintenance treatment is needed critically. Increased tumour vascular endothelial growth factor (VEGF) expression is associated with a poor prognosis (Paley et al, 1997) supporting the role of angiogenesis in the progression of this disease, in vivo neutralisation of VEGF with antisera has been shown to inhibit tumour growth and ascites (Olson et al, 1996). The regulatory tetradecapeptide somatostatin (SRIF), exhibits anti-proliferative (Buscail et al, 1994; Florio et al, 1996; Srikant, 1997), anti-angiogenic (Patel et al, 1994; Albini et al, 1999) and pro-apoptotic actions (Sharma et al, 1996). These effects are mediated through a family of five trans-membrane G-protein coupled somatostatin (SRIF) receptors, which have been cloned (Hoyer et al, 1995), activate multiple post-receptor signal transduction pathways (Patel, 1999). Synthetic SRIF analogues such as SMS-201-995 (Sandostatin, octreotide), RC-160 (Vapreotide, octastatin) and BIM-23014 (Lanreotide, somatuline) have been developed which have varying binding affinities for different receptor subtypes. They have been shown to potentiate the effects of

*Correspondence: Dr GH Hall, Centre for Magnetic Resonance Investigation, Hull Royal Infirmary, Anlaby Road, Hull, HU3 2JZ, UK;

E-mail: cbvghh@aol.com

Received 2 November 200I; revised 26 February 2002; accepted 27 February 2002 tamoxifen in the inhibition of growth of mammary carcinomas in nude mice (Weckbecker et al, 1994) and to control growth of Kaposi's sarcoma by inhibition of angiogenesis (Albini et al, 1999). Recently in a cohort of 15 serous and two mucinous ovarian cystadenocarcinomas, $76 \%$ have been shown to demonstrate high affinity binding sites for the analogue RC-160 and RT-PCR has shown expression of mRNA for sst $_{1}(65 \%)$, sst $_{2 \mathrm{~A}}(65 \%)$, sst $_{3}$ (41\%) and $s_{5}$ (24\%) (Halmos et al, 2000). Therefore SRIF analogues may have a role as anti-angiogenic agents in the maintenance therapy of ovarian carcinoma. In order to explore the potential role of native SRIF in ovarian cancer, to further determine the localisation and expression of the SRIF receptors in a variety of ovarian neoplasms, we have examined the expression of both in a cohort of 63 malignant and 35 benign ovarian tumours, of various histological types, using immunohistochemistry.

\section{MATERIALS AND METHODS}

\section{Experimental subjects}

Permission was obtained from the local ethics committee to access material from the pathology archives at Hull and East Yorkshire NHS Hospitals Trust (Hull, UK). Representative paraffin blocks were taken from a cohort of 63 malignant and 35 benign ovarian tumours of mixed histological type. The mean age of patients studied was 57 years (range $30-84$ ) with benign and 59 years (range 26-85) for malignant disease. According to Federation International of Gynaecology and Obstetrics (FIGO) classification for malignant ovarian disease 24 cases were stage I, seven were stage II and 32 were stage III. The histopathology of the tumours 
Table I Histopathology and number of tumours staining positive in each group for SRIF and its receptors

\begin{tabular}{|c|c|c|c|c|c|c|c|c|c|c|c|c|c|c|c|c|}
\hline \multirow[b]{2}{*}{ Histology } & \multirow[b]{2}{*}{ Total } & \multicolumn{3}{|c|}{ SRIF } & \multicolumn{3}{|c|}{ sst $_{\mathbf{l}}$} & \multicolumn{3}{|c|}{ sst $_{2}$} & \multicolumn{3}{|c|}{ sst $_{3}$} & \multicolumn{3}{|c|}{ sst $_{5}$} \\
\hline & & $\mathbf{E}$ & $\mathbf{v}$ & $\mathbf{S}$ & $\mathbf{E}$ & $\mathbf{v}$ & $\mathbf{s}$ & $\mathbf{E}$ & $\mathbf{v}$ & $\mathbf{S}$ & $\mathbf{E}$ & $\mathbf{v}$ & $\mathbf{S}$ & $\mathbf{E}$ & $\mathbf{v}$ & $\mathbf{s}$ \\
\hline Serous cystadenocarcinoma & 23 & 17 & 4 & 8 & 14 & 12 & 14 & 8 & 4 & 15 & 0 & 0 & 2 & 10 & 0 & 4 \\
\hline Undifferentiated carcinoma & 8 & 6 & 2 & 3 & 3 & । & 2 & 2 & 5 & 3 & । & 0 & 2 & 5 & 2 & 5 \\
\hline Miscellaneous malignancy & 15 & 8 & 3 & 9 & 6 & 5 & 7 & 4 & 7 & 9 & I & I & 3 & 8 & I & 6 \\
\hline Total n (\%) & $\begin{array}{c}63 \\
(100)\end{array}$ & $\begin{array}{c}45 \\
(71.4)\end{array}$ & $\begin{array}{c}10 \\
(15.9)\end{array}$ & $\begin{array}{c}30 \\
(47.6)\end{array}$ & $\begin{array}{c}32 \\
(50.8)\end{array}$ & $\begin{array}{c}23 \\
(36.5)\end{array}$ & $\begin{array}{c}32 \\
(50.8)\end{array}$ & $\begin{array}{c}19 \\
(30.2)\end{array}$ & $\begin{array}{c}23 \\
(36.5)\end{array}$ & $\begin{array}{c}36 \\
(57.1)\end{array}$ & $\begin{array}{c}10 \\
(15.9)\end{array}$ & $\begin{array}{c}2 \\
(3.2)\end{array}$ & $\begin{array}{c}10 \\
(15.9)\end{array}$ & $\begin{array}{c}33 \\
(52.4)\end{array}$ & $\begin{array}{c}3 \\
(4.8)\end{array}$ & $\begin{array}{c}21 \\
(33.3)\end{array}$ \\
\hline Indeterminate cyst & 8 & I & 5 & 3 & 1 & 4 & 7 & 0 & 5 & 3 & 0 & 0 & 2 & I & 4 & 2 \\
\hline Mature teratoma & 5 & 4 & 2 & 0 & 4 & 4 & 2 & I & I & 1 & 0 & 0 & I & 3 & 1 & 1 \\
\hline Serous cyst & 2 & I & 0 & 0 & I & 0 & 0 & I & 2 & 1 & I & I & 2 & I & 2 & 1 \\
\hline Mucinous cystadenoma & 10 & 10 & I & 3 & 10 & 6 & 7 & I & 2 & 6 & 6 & 0 & 2 & 8 & 3 & 2 \\
\hline Endometriotic cyst & 3 & 0 & 1 & 2 & 2 & I & 2 & 0 & 1 & 2 & 0 & 0 & 2 & I & 2 & 0 \\
\hline Cystadenofibroma & 3 & 2 & 0 & 0 & 2 & 0 & 0 & I & । & 0 & 0 & 0 & 0 & 2 & I & 0 \\
\hline Total n (\%) & $\begin{array}{c}35 \\
(100)\end{array}$ & $\begin{array}{c}19 \\
(54.3)\end{array}$ & $\begin{array}{c}10 \\
(28.6)\end{array}$ & $\begin{array}{c}8 \\
(22.9)\end{array}$ & $\begin{array}{c}21 \\
(60.0)\end{array}$ & $\begin{array}{c}15 \\
(42.9)\end{array}$ & $\begin{array}{c}19 \\
(54.3)\end{array}$ & $\begin{array}{c}5 \\
(14.3)\end{array}$ & $\begin{array}{c}12 \\
(34.3)\end{array}$ & $\begin{array}{c}14 \\
(40.0)\end{array}$ & $\begin{array}{c}7 \\
(20.0)\end{array}$ & $\begin{array}{c}\text { I } \\
(2.9)\end{array}$ & $\begin{array}{c}10 \\
(28.6)\end{array}$ & $\begin{array}{c}17 \\
(48.6)\end{array}$ & $\begin{array}{c}14 \\
(40.0)\end{array}$ & $\begin{array}{c}6 \\
(17.1)\end{array}$ \\
\hline
\end{tabular}

E=epithelium; V=vessels; S=stroma.

analysed with immunohistochemistry is summarised in Table 1. The wide mix of histological subtypes is representative of the breadth of ovarian tumours seen in clinical practice. The miscellaneous group of malignant tumours included two granulosa cell tumours, one carcinosarcoma, two clear cell adenocarcinomas, one malignant carcinoid tumour, one Leydig cell tumour and eight miscellaneous adenocarcinomas.

\section{Immunohistochemistry}

Five-micrometer thick paraffin sections were dewaxed and antigen retrieval performed by microwaving at $600 \mathrm{~W}$ power in $10 \mathrm{~mm}$ citric acid for $20 \mathrm{~min}$. Serial sections were stained with SRIF and SRIF receptor antibodies to facilitate comparisons between sections.

\section{Somatostatin}

Tissue sections were pre-incubated in $10 \%$ non-immune goat serum (Dako Ltd, Ely, UK) for $20 \mathrm{~min}$, then incubated with primary rabbit anti-SRIF antibody (AHP533, Serotec, UK) at a dilution of $1: 40$, overnight at $4^{\circ} \mathrm{C}$. This antibody recognises both SRIF-14 and SRIF-28 variants. Sections were then washed with PBS, incubated with biotinylated goat anti-rabbit IgG (Dako Ltd, Ely, UK) at a dilution of $1: 200$ for $60 \mathrm{~min}$, washed again with PBS and then HRP-StrepABC (PK-6100; Vector, Burlingame, CA, USA) was added for $45 \mathrm{~min}$. Visualisation was achieved using DAB (Sigma-Aldrich Co Ltd, Poole, Dorset, UK) as an enzyme substrate, counterstained with haematoxylin, dehydrated and mounted.

\section{Somatostatin receptors}

For SRIF receptor immunohistochemistry rabbit polyclonal antibodies to $\mathrm{st}_{1,2}$ and 5 were produced and provided by Dr Helboe as previously described (Helboe et al, 1997). Rabbit polyclonal antisst $_{3}$ antibody was obtained from Gramsch Laboratories (Schwabhausen, Germany). Sections were pre-incubated in 5\% nonimmune swine serum (Dako Ltd, Ely, UK) in PBS ( $\mathrm{pH} 7.4$ ) with $1 \%$ bovine serum albumin (BSA) and $0.3 \%$ Triton $\mathrm{X}-100$ for $20 \mathrm{~min}$ at room temperature. Rabbit anti-SRIF receptor IgG was then added diluted in PBS plus $1 \%$ BSA and $0.3 \%$ Triton X-100, overnight at $4{ }^{\circ} \mathrm{C}$. Dilutions used were $1: 8000$ for $\mathrm{sst}_{1}, 1: 10000$ for sst $_{2} 1: 5000$ for $\mathrm{sst}_{3}$ and 1:7000 for $\mathrm{sst}_{5}$. Sections were washed with PBS containing $0.25 \%$ BSA and $0.05 \%$ Tween-20, incubated with biotinylated swine anti-rabbit IgG (E0353, Dako Ltd, Ely, UK) at 1:500 dilution for $60 \mathrm{~min}$ at room temperature. Sections were then washed in PBS with $0.05 \%$ Tween-20, incubated with tyramide blocking buffer (supplied with the biotinylated tyramide kit; NEL700; NEN Life Science Products, Boston, MA, USA) for $20 \mathrm{~min}$, then incubated with HRP-StrepABC (PK-6100; Vector, Burlingame, CA, USA) for $45 \mathrm{~min}$. Sections were again washed with PBS containing $0.05 \%$ Tween-20, biotinylated tyramide was then added at 1:100 dilution for $10 \mathrm{~min}$, sections were washed again in PBS containing $0.05 \%$ Tween-20, incubated with HRPStrepABC for $45 \mathrm{~min}$, washed again with $\mathrm{PBS}$ and signal visualised with $\mathrm{DAB}$ prior to counterstaining, dehydrating and mounting.

Positive control experiments included normal human anterior pituitary, which stained positively for all the SRIF receptors, normal human pancreas, which stained positively for native SRIF. Negative controls included adsorption studies as previously described (Helboe et al, 1997), which abolished positive staining. In addition omission of the primary antibody and incubation with $1 \%$ non-immune serum also abolished positive staining.

Staining was graded by intensity into negative, weak, moderate or strong and the pattern of staining described as either focal or uniform. The tissue compartments that stained were classified into stromal, epithelial or vascular and the intensity of staining was graded for each.

\section{Statistical analysis}

Results were tabulated and data analysed using the SPSS statistical package (SPSS Professional Statistics, SPSS Inc., Illinois, USA). The $\chi^{2}$ square test was used for differences in staining between benign and malignant groups and a probability of $P<0.05$ was considered to be statistically significant. The Spearman Rank test was employed to determine correlations coefficients between native SRIF and its receptor expression.

\section{RESULTS}

\section{SRIF expression}

Fifty-seven out of 63 (90\%) of malignant and 26 out of 35 (74\%) of benign tumours expressed native somatostatin (SRIF). An example of a serous cystadenocarcinoma stained for SRIF is shown in Figure 1. There was a trend toward more frequent expression in the epithelium of malignant tumours $(71.4 \%)$ compared to benign 
(54.3\%) although this failed to reach statistical significance (Table 1). There was significantly higher expression of SRIF in the vessels of benign tumours $(28.6$ vs $15.9 \% ; P=0.044)$ but the stromal expression was significantly higher in the malignant tumours (47.6 vs $22.9 \% ; P=0.005$ ).

\section{SRIF receptor expression}

Epithelial staining for the SRIF receptors was uniform where present. An endometrioid adenocarcinoma demonstrating epithelial expression of $\mathrm{sst}_{5}$ is shown in Figure 2. Vascular staining was largely found in the smooth muscle of the tunica media of arteries and veins and was fairly uniform, although some endothelial staining was also seen (Figure 3). Stromal staining was more focal and patchy (Figure 4).

Forty-eight out of $63(76 \%)$ of malignant and 30 out of 35 $(86 \%)$ benign tumours expressed sst $_{1}$. There was significantly more frequent expression of $s t_{1}$ in the epithelium (60\%) of benign as compared with malignant $(50.8 \%)$ tumours $(P=0.034)$ although there were no differences between vascular and stromal staining (Table 1).

There was significantly more frequent expression of $s_{2} t_{2}$ in malignant tumours in both the epithelium (30.2 vs 14.3\%;

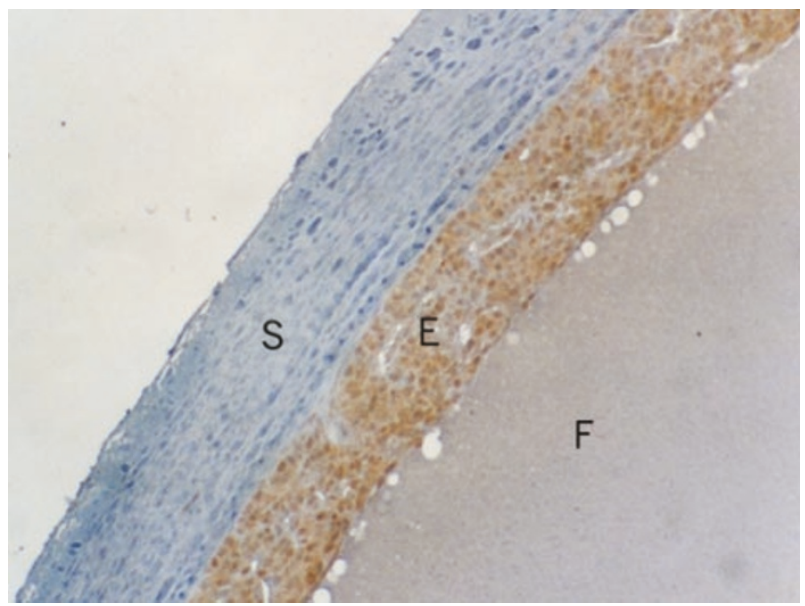

Figure I A serous cystadenocarcinoma demonstrating strong expression of SRIF by the malignant epithelium. S=Stroma, E=malignant epithelium, $\mathrm{F}=$ fluid in the cystic tumour (magnification $\times 200$ ).

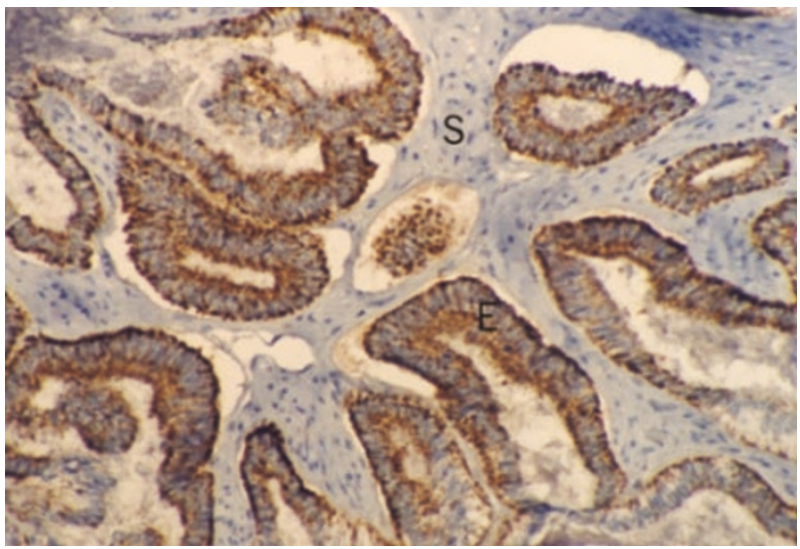

Figure 2 Ovarian endometrioid adenocarcinoma demonstrating uniform membrane bound epithelial staining for sst ${ }_{5}$. E=Epithelium; $\mathrm{S}=$ stroma (magnificatoin $\times 200$ )
$P=0.044)$ and stroma (57.1 vs $40 \% ; P=0.018$ ) (Table 1 ). There was no difference in the vascular staining. It is of interest that five out of eight $(62.5 \%)$ of undifferentiated carcinomas expressed vascular sst $_{2}$ receptors. Overall 46 out of $63(77 \%)$ of malignant tumours and 21 out of $35(60 \%)$ of benign tumours expressed $s^{2} t_{2}$ in at least one of the tissue compartments.

sst $_{3}$ was the least expressed of the receptors studied, with overall only 18 out of $63(29 \%)$ of malignant and 16 out of $35(45 \%)$ of benign tumours expressing it. Both six out of eight $(75 \%)$ mucinous cystadenocarcinomas and six out of 10 (60\%) mucinous cystadenomas demonstrated epithelial $\mathrm{sst}_{3}$ (Table 1). Three tumours demonstrated vascular expression of $\mathrm{sst}_{3}$.

Forty-five out of $63(71 \%)$ of malignant and 25 out of $35(71 \%)$ of benign tumours demonstrated expression of sst $_{5}$. There were no significant differences in epithelial or stromal expression between benign and malignant tumours, but benign tumours expressed significantly higher amounts of vascular sst $_{5} \quad\left(\begin{array}{lll}40 & \text { vs } & 4.8 \% \text {; }\end{array}\right.$ $P<0.001$ ) (Table 1).

\section{Correlation of SRIF with receptor expression}

Native SRIF expression was found to correlate strongly with receptor expression in the same tissue compartments in both benign and

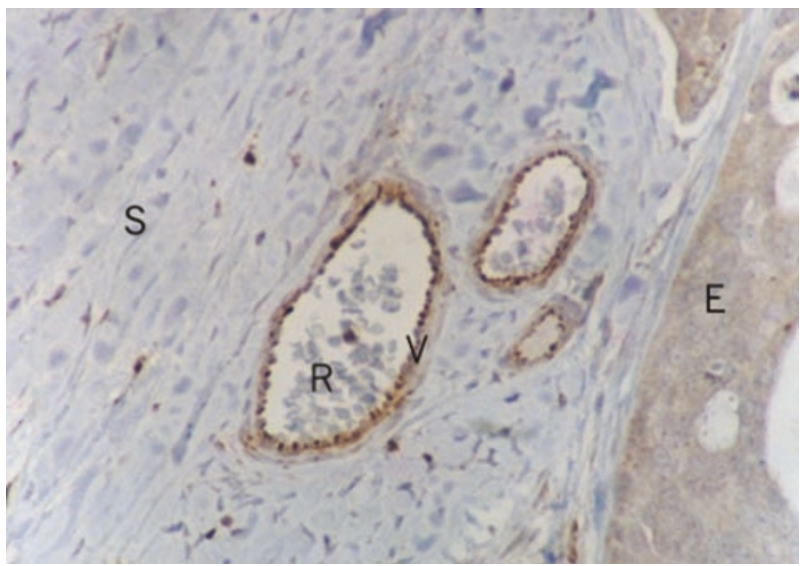

Figure 3 Endothelial sst, expression in small tumour venules. $V=V$ enule $\mathrm{R}=$ red blood cells within vessel lumen, $\mathrm{S}=$ stroma, $\mathrm{E}=$ malignant epithelium (magnification $\times 400$ ).

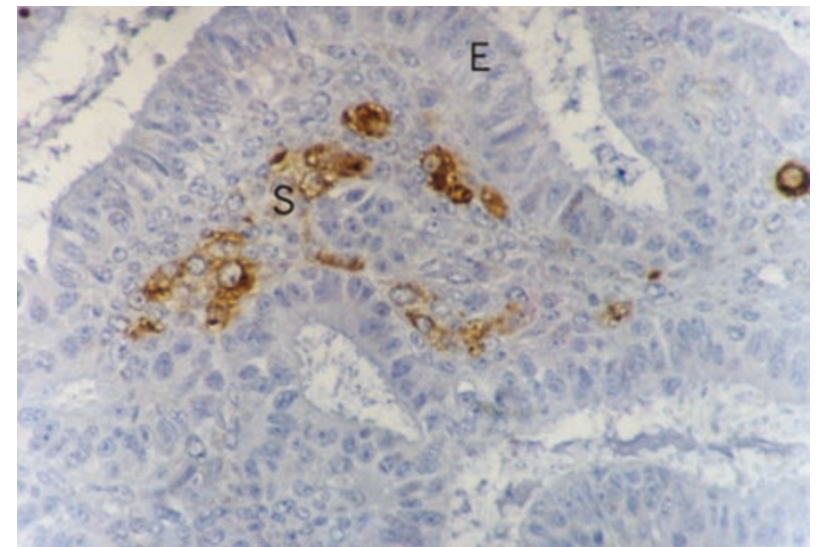

Figure 4 Ovarian adenocarcinoma demonstrating focal expression of sst, on non-malignant stromal cells. There is both membrane bound and intracellular staining. E=Epithelium, S=stroma (magnification $\times 400$ ). 
malignant tumours, as follows: stromal sst ${ }_{1}(P=0.008)$, epithelial sst $_{1}(P<0.001)$, stromal sst $_{2}(P=0.019)$, vascular sst $_{2}(P=0.026)$, epithelial sst $3(P=0.026)$, stromal sst ${ }_{5}(P=0.013)$ and vascular sst $_{5}$ $(P=0.038)$.

\section{DISCUSSION}

The results form this large cohort of benign and malignant ovarian tumours show that both express high levels of native SRIF as well as the receptors $s_{1,2,3}$ and 5 . We aimed specifically to determine whether malignant epithelium and blood vessels, as well as supporting stromal cells, expressed SRIF or its receptors. The presence of SRIF receptors on malignant epithelium is of great relevance to the potential use of SRIF analogues as chemotherapeutic agents, as is the presence of receptors on blood vessels for the potential use of SRIF analogues as anti-angiogenic therapy.

The expression of native SRIF by epithelial ovarian tumours is intriguing and its relationship with its receptor expression has not been well documented. SRIF occurs naturally in two forms, a 14 amino acid form (SRIF-14) and a 28 amino acid form (SRIF28). Both are biologically active and bind to receptors. SRIF has previously been shown to be expressed by neuroendocrine ovarian carcinoid tumours (Sporrong et al, 1982). These tumours are exceptionally rare and demonstrate a different biological and clinical behaviour to the common epithelial ovarian tumours. SRIF mRNA production has been demonstrated in 14 out of 30 ovarian adenocarcinomas and two out of three borderline tumours (Reubi et al, 1993). In that study translation of mRNA was not confirmed by examining peptide expression and receptor autoradiography demonstrated SRIF receptors in only two of the 33 ovarian tumours. SRIF production has been demonstrated in the normal ovaries of many species, but in the human ovary it has only been demonstrated in follicular fluid to date (Holst et al, 1994). In this study we have examined the expression of both forms of SRIF in ovarian neoplasms, but have not examined expression in normal ovarian tissue.

As the actions of SRIF are inhibitory in most biological systems, it might have been expected that SRIF be expressed in benign lesions and this expression lost in malignancy. This was not the case, however, and raises further questions as to the role of SRIF in the pathophysiology of ovarian disease. Epithelial expression of SRIF was much greater than vascular or stromal, most of the SRIF staining was in the malignant cells themselves. The high levels of SRIF in ovarian malignancy may even suggest a stimulatory role in tumour growth through an autocrine positive feedback loop, perhaps involving up-regulation of receptors. This would not be unique, as SRIF-14 has been reported to stimulate tumour growth in the SHP-1 deficient pancreatic cell line MIA PaCa-2 whilst it inhibits growth in the SHP-1 positive PANC-1 cell line (Douziech et al, 1999). Further work is required to investigate the role of SHP-1 in ovarian cancer and to explore the actions of SRIF on the dynamics of tumour cells.

This study confirms that most ovarian tumours express SRIF receptors, but shows that there are differences in expression pattern between benign and malignant groups and between histological types. The malignant epithelium of ovarian tumours expresses high levels of sst ${ }_{1,2}$ and 5 as well as SRIF itself. This suggests that SRIF may have a role in the progression of ovarian cancer. sst $_{3}$ was only expressed in low amounts, as it is the receptor subtype thought to be most involved in stimulating apoptosis (Sharma et al, 1996), its low expression may be a significant factor in tumour progression. The strong correlations seen between SRIF and its receptors suggest that SRIF can cause up-regulation of its own receptors and be involved in auto-regulation of tumour growth. Of particular note is that vessels within even the most undifferentiated anaplastic tumours still express SRIF receptors and thus may be potential targets for therapy with the anti-angiogenic synthetic SRIF analogues.
An early report of SRIF receptor expression in ovarian tumours using in vitro receptor autoradiography found only 3/57 positive tumours (Reubi et al, 1991). A recent rapid communication of 15 serous and two mucinous cystadenocarcinomas, used radiolabelled RC-160 binding assays, specific for $\mathrm{sst}_{2}$ and $5, \mathrm{RT}-\mathrm{PCR}$, to demonstrate expression of SRIF receptors in malignant ovarian tumours (Halmos et al, 2000). Whilst confirming that these two types of tumour expressed SRIF receptors, this methodology did not allow the anatomical localisation of receptor expression with respect to the malignant cells or surrounding normal stromal tissues. This is important to our understanding of the pathophysiology of the disease and how specific receptor targeting may act therapeutically.

SRIF analogues may exert their effects through both direct and indirect mechanisms (Pollak and Schally, 1998). Thus, even if tumour cells themselves do not express SRIF receptors, analogues may still inhibit tumour growth by indirect actions on other cells. One example of this is prevention of proliferation of an SRIF receptor-negative chondrosarcoma by the analogue SMS201-995 via inhibition of growth hormone, insulin like growth factor-1 (IGF1) and insulin (Reubi, 1985). In Kaposi's sarcoma models, both in vitro and in vivo, SRIF has been shown to be a pure anti-angiogenic agent in its own right, inhibiting growth of SRIF receptor negative tumours (Albini et al, 1999). The stromal expression of SRIF and its receptors is important in many body systems, and is likely to be so in ovarian cancer too. The subtle interactions between malignant cells and their supporting stroma are poorly understood. Tumour associated macrophages have been reported in both benign and malignant ovarian tumours (Orre and Rogers, 1999), have been shown to have positive influence on tumour vascularisation. Some of the stromal cells expressing SRIF receptors (e.g. Figure 4) may be tumour-associated macrophages, it is possible that SRIF analogues might effect an action through this route. The demonstration of expression of SRIF receptors on stromal cells within ovarian tumours means that SRIF analogues could potentially alter tumour growth indirectly, by inhibiting stromal cell production of growth factors.

SRIF receptors have been described in both normal human blood vessels (Curtis et al, 2000) and veins surrounding human cancers (Reubi et al, 1994, 1996). IGF-1 stimulates growth of new blood vessels in experimental systems (Nakao-Hayashi et al, 1992) and potentially SRIF analogues may inhibit tumour growth indirectly by decreasing IGF-1 production. As SRIF receptors are expressed on peritumoral vessels they may act directly to inhibit angiogenesis or affect tumour biology by causing vasoconstriction and thus decreasing tumour blood flow (Reubi et al, 1996). The post-receptor signal transduction pathways in octreotide-induced inhibition of angiogenesis have been studied in the chick embryo system and have been shown to depend on G proteins, calcium and cyclic adenosine monophosphate (Patel et al, 1994). Our study has shown high-level expression of sst $_{1}$ and sst $_{2}$ in the vessels of both benign and malignant ovarian tumours, so there is potential for SRIF analogues to inhibit angiogenesis by both direct and indirect mechanisms. Vascular sst ${ }_{5}$ was expressed in $40 \%$ of benign and only $4.8 \%$ of malignant lesions, which may suggest that either the loss of $s t_{5}$, which is postulated to have tumour suppressor actions, by benign vessels leads to the more rapid angiogenesis associated with malignancy, or that the increased production of SRIF by malignant lesions may lead to down-regulation of the vascular $\mathrm{sst}_{5}$ receptors.

Studies are already underway to look at the potential role of SRIF analogues in therapy of other solid tumours. SRIF analogues have been shown to be beneficial in a rat model where they potentiate the effects of tamoxifen (Weckbecker et al, 1994) and clinical trials in advanced breast cancer are underway (Bontenbal et al, 1998; O’Byrne et al, 1999). In ovarian cancer models the anti-angiogenic agents endostatin and angiostatin have been shown 
to act synergistically to inhibit tumour growth (Yokoyama et al, 2000). There is also evidence that the SRIF analogue RC-160 can inhibit growth of the ovarian cell line OV-1063 (Yano et al, 2000), but it cannot be extrapolated that this is true of all ovarian tumours in vivo. This gives hope that SRIF analogues may also prove efficacious by a combination of both the direct and indirect mechanisms. The cytotoxic SRIF analogue AN-238 has been shown to inhibit proliferation of SRIF receptor positive cells from the UCI-107 ovarian carcinoma cell line in vitro (Plonowski et al, 2001). Our study provides further rationale for exploring the

\section{REFERENCES}

Albini A, Florio T, Giunciuglio D, Masiello L, Carlone S, Corsaro A, Thellung S, Cai T, Noonam DM, Schettini G (1999) Somatostatin controls Kaposi's sarcoma tumor growth through inhibition of angiogenesis. FASEB J 13: $647-655$

Bontenbal M, Foekens JA, Lamberts SWJ, de Jong FH, van Putten WLJ, Braun HJ, Burghouts JThM, van der Linden GHM, Klijn JGM (1998) Feasibility, endocrine and anti-tumor effects of a triple endocrine therapy with tamoxifen, a somatostatin analogue and an anti-prolactin in postmenopausal metastatic breast cancer: a randomised study with long-term follow-up. Br J Cancer 77: 115-122

Buscail L, Delesque N, Esteve JP, Saint-Laurent N, Prats H, Clerc P, Robberecht P, Bell GI, Liebow C, Schally AV (1994) Stimulation of tyrosine phosphatase and inhibition of cell proliferation by somatostatin analogues: mediation by human somatostatin receptor subtypes SSTR1 and SSTR2. Proc Natl Acad Sci USA 91: 2315-2319

Curtis SB, Hewitt J, Yakubovitz S, Anzarut A, Hsiang YN, Buchan AMJ (2000) Somatostatin receptor subtype expression and function in human vascular tissue. Am J Physiol Heart Circ Physiol 278: H1815-H1822

Douziech N, Calvo E, Coulombe Z, Muradia G, Bastien J, Aubin RA, Lajas A, Morisset J (1999) Inhibitory and stimulatory effects of somatostatin on two human pancreatic cancer cell lines: A primary role for tyrosine phosphatase SHP-1. Endocrinology 140: $765-777$

Florio T, Scorizello A, Fattore M, D’Alto V, Salzano S, Rossi G, Berlingieri MT, Fusco A, Schettini G (1996) Somatostatin inhibits PC C13 thyroid cel proliferation through the modulation of phosphotyrosine activity. Impairment of the somatostatinergic effects by stable expression of the E1A viral oncogene. J Biol Chem 271: 6129-6136

Halmos G, Sun B, Schally AV, Hebert F, Nagy A (2000) Human ovarian cancers express somatostatin receptors. J Clin Endocrin Metab 85: 3509 3512

Helboe L, Moller M, Norregaard L, Schiodt M, Stidsen CE (1997) Development of selective antibodies against the human somatostatin receptor subtypes sst $_{1}-$ sst $_{5}$. Mol Brain Res 49: $82-88$

Holst N, Haug E, Tanbo T, Abyholm T, Jacobsen MB (1994) Somatostatin in human follicular-fluid. Hum Reprod 9: 1448-1451

Hoyer D, Bell GI, Berelowitz M, Epelbaum J, Feniuk W, Humphrey PPA, O’Carroll A-M, Patel YC, Schonbrunn A, Taylor JE, Reisine T (1995) Classification and nomenclature of somatostatin receptors. TiPS 16: $86-88$

Nakao-Hayashi J, Ito H, Kanayasu T, Morita I, Murota S (1992) Stimulatory effects of insulin and insulin-like growth factor I on migration and tube formation by vascular endothelial cells. Atherosclerosis 92: 141 - 149

O’Byrne KJ, Dobbs N, Propper DJ, Braybrooke JP, Koukourakis MI, Mitchell K, Woodhull J, Talbot DC, Schally AV, Harris AL (1999) Phase II study of RC-160 (vapreotide), octapeptide analogue of somatostatin, in the treatment of breast cancer. Br J Cancer 79: 1413-1418

Office for National Statistics (1998) Cancer 1971-1997. London: Office for National Statistics

Olson TA, Mohanraj D, Ramakrishnan S (1996) in vivo neutralisation of vascular endothelial growth factor (VEGF)/ vascular permeability factor (VPF) inhibits ovarian carcinoma-associated ascites formation and tumor growth. Intl J Oncol 8: 505-511 potential therapeutic use of cytotoxic radionulide SRIF analogues in clinical trials of ovarian cancer.

We have shown the expression of SRIF and its receptors in both the epithelial and vascular compartments of benign and malignant epithelial ovarian tumours and have also noted significant stromal expression. It is likely that $s t_{1,2}$ and 5 will be more clinically important targets than $\mathrm{sst}_{3}$ for analogue mediated therapy. The role of SRIF and its receptors in the pathophysiology of ovarian disease requires further investigation as it may have either stimulatory or inhibitory actions.
Orre M, Rogers PAW (1999) Macrophages and microvessel density in tumors of the ovary. Gynecol Oncol 73: 47-50

Paley PJ, Staskus KA, Gebhard K, Mohanraj D, Twiggs LB, Carson LF, Ramakrishnan S (1997) Vascular endothelial growth factor expression in early stage ovarian carcinoma. Cancer 80: $98-106$

Patel PC, Barrie R, Hill N, Landeck S, Kurozawa D, Woltering EA (1994) Postreceptor signal transduction mechanisms involved in octreotideinduced inhibition of angiogenesis. Surgery 116: $1148-1152$

Patel YC (1999) Somatostatin and its receptor family. Front Neuroendocrinol 20: $157-198$

Plonowski A, Schally AV, Koppan M, Nagy A, Arencibia JM, Csernus B, Halmos G (2001) Inhibition of the UCI-107 human ovarian carcinoma cell line by a targeted cytotoxic analog of somatostatin, AN-238. Cancer 92: $1168-1176$

Pollak MN, Schally AV (1998) Mechanisms of antineoplastic action of somatostatin analogs. Proc Soc Exper Biol Med 217: 143-152

Reubi JC (1985) A somatostatin analogue inhibits chondrosarcoma and insulinoma tumour growth. Acta Endocrinol 109: 108-114

Reubi JC, Horisberger U, Klijn JGM, Foekens JA (1991) Somatostatin receptors in differentiated ovarian tumors. Am J Pathol 138: 1267-1272

Reubi JC, Waser B, Lamberts SW, Mengod G (1993) Somatostatin (SRIF) messenger ribonucleic acid expression in human neuroendocrine and brain tumours using in situ hybridisation histochemistry: comparison with SRIH receptor content. JCEM 76: 642-647

Reubi JC, Horisberger U, Laissue J (1994) High density of somatostatin receptors in veins surrounding human cancer tissue: Role in tumour-host interaction? Int J Cancer 56: 681-688

Reubi JC, Schaer J-C, Laissue JA, Waser B (1996) Somatostatin receptors and their subtypes in human tumors and in peritumoral vessels. Metabolism $\mathbf{4 5}$ $39-41$

Sharma K, Patel YC, Srikant CB (1996) Subtype-selective induction of wildtype p53 and apoptosis, but not cell cycle arrest, by human somatostatin receptor 3. Mol Endocrinol 10: $1688-1696$

Sporrong B, Falkmer S, Robboy SJ, Alumets J, Hakanson R, Ljungberg O, Sundler F (1982) Neuro-hormonal peptides in ovarian carcinoids - an immunohistochemical study of 81 primary carcinoids and of intra-ovarian metastases from 6 midgut carcinoids. Cancer 49: $68-74$

Srikant CB (1997) Human somatostatin receptor mediated antiproliferative action evokes subtype selective cytotoxic and cytostatic signalling. Yale J Biol Med 70: $541-548$

Weckbecker G, Tolcsvai L, Stolz B, Pollak M, Bruns C (1994) Somatostatin analogue octreotide enhances the antineoplastic effects of tamoxifen and ovariectomy on 7,12-dimethylbenz(a)anthracene-induced rat mammary carcinomas. Cancer Res 54: 6334-6337

Yano T, Radulovic S, Osuga Y, Kuga K, Yoshikawa H, Taketani Y, Schally AV (2000) Inhibition of human epithelial ovarian cancer cell growth in vitro by somatostatin analog RC-160. Oncology 59(suppl 1): 45-49

Yokoyama Y, Dhanabal M, Griffioen AW, Sukhatme VP, Ramakrishnan S (2000) Synergy between angiostatin and endostatin: Inhibition of ovarian cancer growth. Cancer Res 60: 2190-2196 